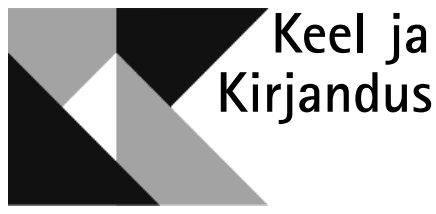

\title{
KARL RISTIKIVI RÄNDAV ARKAADIA
}

\author{
JANIKA KRONBERG, BRITA MELTS
}

$\mathrm{K}$

ojuigatsus - kauguseigatsus... See vastandeid kätkev sõnapaar juhatab sisse eesti kirjanduse ühe mõjukaima luulekogu - Karl Ristikivi „Inimese teekonna” (1972). Ja kuivõrd Karl Ristikivi ise käsitas oma luulet psühhoteraapiana, osutab see sõnapaar ühtlasi katsele lepitada indiviidi unistusi ja lootusi karmi tegelikkusega. Silmas pidades luuletuse kirjutamise ligikaudset aega (tõenäoliselt jääb see 1950. aasta ja kogu ilmumisele eelnenud komponeerimise avarasse vahemikku) ja tingimusi, nähkem siin autoripoolset rõhu asetamist sõnapaari teisele poolele. Nimelt on kuue aasta jooksul end maapagulase leivaga harjutanud - kui sellega üldse saab harjuda! - Ristikivi usalduslikult kirjutanud oma sõbrale Otto A. Webermannile Saksamaale, et vaevalt teda rõõmustaks päev, mil avaneks võimalus kodumaale tagasi pöörduda: „Mis muidugi ei tähenda, et ma seda päeva kõigest südamest ei ootaks. Aga ainult nende pärast, kes praegu on seal või veel kaugemal ida pool. Tunnen selgesti, et oleksin seal sama võõras kui siin või kuski mujal. Jah, päris eksootilised maad (ja Pariis) välja arvatud. Siin vahest on peidetud ka sügavam põhjus, miks mul täiesti võimatu on midagi kirjutada. Mul pole ütelda midagi niisugust, mida rahvas ootab. Siin ei saa ma võistelda ei Viirlaiuga ega Salme Ekbaumiga" (Ristikivi 1995: 83).

Pangem tähele, et need read on kirjutatud 25. novembril 1950 ehk samal aastal, mil ajakirja Tulimuld avanumbris ilmus varem tunnustatud proosameistri Ristikivi sulest üheksast luuletusest koosnev luuletsükkel „Hårsfjärden", mille nimi pakub mitmeid seletusvõimalusi, ent tõenäoliselt viitab Stockholmi saarestikku kuuluvale merelahele. Hiljem on kirjanik ise tagasi- 
hoidlikult manitsenud oma luuledebüüti mitte väga tõsiselt võtma, kuid siinse teemaarenduse seisukohalt on oluline, et just sellesse tsüklisse, mis algselt pidi kandma pealkirja „Võõrad paigad” (Kangro, Ristikivi 2006: 41), kuulub ka Ristikivi tuntuim luuletus „Minagi olin Arkaadia teel...”. Teisal on Ristikivi andnud mõista, et kui pagulus võttis temalt kodumaa, andsid avarduvad elutingimused uuel asukohamaal koduigatsuse leevendamiseks vastu teise võimaluse: „Võimalus rännata, asukohta vahetada, võib teinekord olla ka lohutus", on ta kirjutanud Vello Sermatile 30. märtsil 1977 (Ristikivi 2002: 424). Varajast vastuvõtlikkust kauguseigatsusele tunnistab juba Ristikivi noorpõlveloomingusse kuuluvas seiklusromaanis „Viikingite jälgedes” ette võetud Kolumbuse-eelne Ameerika avastamise retk. Hilisem hea haridus maateaduses ja süvenev huvi Euroopa ajaloo vastu olid nii edasiste reiside eelduseks kui ka ajendiks.

Kui aga nii geograafilisest kui ajaloolisest reaalsusest napiks jääb, tuleb loomingus juurde luua uusi paiku - nagu utoopiline Allotria „Imede saares” või laenata antiikmütoloogia ammendamatust varamust ning töödelda ja arendada edasi tuntud motiive.

Ühe sellise antiikkultuurist alguse saanud kujundina on Ristikivi loomingus silmapaistval kohal Arkaadia motiiv, mille tunnetuslikku arengut roomlasest Vergiliusest kuni meie Paul-Eerik Rummoni käsitles kirjaniku 75. sünniaastapäeva konverentsil Sirje Kiin. Tuginedes peamiselt romaanile „Rohtaed”, leidis Kiin motiivile neli erinevat tähendust: Arkaadia kui ideaalmaa, Arkaadia kui apolloonlik armastus, Arkaadia kui kodupaik, ning lõpuks Arkaadia kui rohtaed, mida peategelane Juulius Kilimit kogu elu on harinud (Ruutsoo 1988: 80-82). Kas vahepeal möödunud veerandsajand lubab meil lisada tollele tõlgendusele midagi uut, avardada vaatevälja või süvendada Ristikivi Arkaadia-käsituse mõistmist? Kas Arkaadia on pelk kirjanduslik rändmotiiv või avab see tavakäsituse järgi idülli tõotav puhkepaik looja teekonnal ka midagi Ristikivi isikule ja loomingule eriomast? Millise tähendusvarjundi lisab varasematele Arkaadia-motiivi arendustele Ristikivi looming?

Nõnda küsides olemegi lootusrikkalt asunud teele, varustatuna uute seoste avastamise (või ka loomise) võimalustega.

\section{Arkaadia motiivist Euroopa kultuuriloos}

Kui me korraks juba viitasime Arkaadia mõiste ajas muutunud tähendusele ja edaspidi osutame ka Kreeka kuulsast maakonnast nime saanud motiivi topograafilisele paigalpüsimatusele, siis peaks olema põhjendatud meenutada olulisi teelahkmeid Ristikivi-eelse Arkaadia mõiste kujunemisloos. Peloponnesose poolsaare looduslikust alg-Arkaadiast ei ole hilisemas traditsioonis just palju alles jäänud. Nii peaks selguma, millistest kultuuriloo kihistustest pärineb Ristikivi enese arusaam tema loomingusse olulisi jälgi jätnud motiivist. Selles toetume olulisel määral inglise ajaloolase, kunsti- ja kultuurikriitiku Simon Schama kunstiteadusliku monograafia „Landscape and Memory” (1995) peatükile „Arcadia Redesigned”.

Kultuuriloolane Egon Friedell, kelle suurteostega vanaaja ja uusaja kultuuriloost oli Ristikivi tuttav, on algset, Peloponnesose poolsaare keskosas mägisel kõrgmaal asunud peaaegu korrapärase nelinurga kujulist Arkaadiat 
iseloomustanud kui kõikjal kõrgete mägedega piiratud ja lõhestatud paikkonda, „mis on nautinud läbi Helleni kõikide rahutute sajandite idüllilist eripärast eksistentsi. [---] Elu muust maailmast lahutatud mägistes paikades, mis pealegi veel omavahel eraldi hoidusid, oli karm, vilets ja kultuurivaene; ainult muusikaarmastust jagasid arkaadlased kõikide ülejäänud kreeklastega. Paradiisiks tegi Arkaadia alles Aleksandri ajastu suurlinlik sentimentaalsus, ning see kullakord on oma ebaehtsusest hoolimata säilinud kõikide moodsate rahvaste „karjusepoeesia” kaudu meie päevini välja” (Friedell 2010: 18). Algne Arkaadia, mägedest kaitstud sisemaa, oli otsekui lõks, mida looduslikult kujundasid ühelt poolt põuad ja teiselt poolt armutud tulvaveed. Arkaadia oli Kreeka viljatuim maakond ja põlluharimiseks, milleks nagunii terves riigis sobivat maad nappis, täiesti kõlbmatu. Kreeklased ei kujutanudki arkaadlasi kunagi põlluharijatena, nende põhilisteks tegevusaladeks olid karjapidamine, küttimine ja korilus. Kuna arkaadlased olevat pärimuse järgi käitunud ja näinud välja nagu koletised ning paistnud silma brutaalse kalkuse ja himurusega, siis sobis neid värvata ka palgasõduriteks. Arkaadiat hüüti karudemaaks, sest nende eponüümse esiisa Arkase nimi tulenes sõnast árktos ehk karu (Puhvel 1997: 141). Kõnekas on seegi, et müütide kohaselt oli peale Hermese Arkaadiast pärit veel välimuselt loomalike joontega ja liiderlik karjuste jumal Paan. Arkaadia maakonnas arvati voolavat ka surma toova ja järsult langeva veega Styxi jõgi.

Algselt tokerjas ja isegi hirmuäratav Arkaadia ei vastanud niisiis kaugeltki meie praegusele ettekujutusele ideaalmaastikust. Hilisemad ajastud on omaks võtnud kreeka poeedi Theokritose idüllilised kirjeldused III sajandist eKr, mis Simon Schama sõnul oli tegelikult kompositsioon Egeuse oliivisaludest, Egiptuse maisiväljadest ja Sitsiilia viinamarjaaedadest ning kus enamik primitiivse Arkaadia eemaletõukavatest omadustest olid elimineeritud (Schama 1995: 527-528). I sajandil eKr ,istutas” roomlastest kuulsaim kõnealuse motiivi käsitleja, isiklikult põlluharimist tundnud ja harrastanud erakliku loomuga Vergilius taasavastatud Arkaadia, kuhu ta ise kunagi ei sattunud ja mille geograafiline originaal on tema loomingus vaid vilksamisi mainitav võrdlusväli, samuti nendele küpselt külluslikele maastikele. See oli linna ja maa esimene jõuline vastandamine maailma kultuuriloos, rõhuasetusega maaelu hüvedel ja süütusel, osutus Olümpose jumalate eelsele muistsele kuldajastule, mida kirjeldatakse enamjaolt tagasihoidliku karjaste maailmana, kus elati vaikselt, rahulikult, ilma liigsete tööpingutusteta, kus päikeselise taeva all aina armastati ja lauldi, kus puud olid lihavad ja laialehelised, muru pehme, maapind viljakas ning süda muretu - kuigi kohati tunti ka armuvalu, mis omakorda toitis musikaalseid värsse (Oras 1992: 11).

Vergiliuse kaudu leidis Arkaadia tee kogu Euroopa kirjandusse ja nii sai Arkaadiast idülliline, pastoraalne koht, kust kõik metsik oli pagendatud. Nagu „Rooma oli õieti esimene suur kreeka eksportmüüdi tarbija, pärandades ta lääneilma kirjanduslikule ja kultuursele järelpõlvele" (Puhvel 1997: 149), nii pärandas Rooma kultuur edasi ka Arkaadia, juurides ta lahti algsest geograafilisest pinnasest ja andes talle hoopis teistsuguse kuju ning looduslikud tingimused.

Renessansis kaugeneb Arkaadia-motiiv veelgi oma geograafilisest alguspunktist ning omandab üha enam sümboolse tähenduse (Ruutsoo 1988: 77). Magusaid ideaalmaastikke kujutavate pastoraalide prototüübiks võib pidada 
Jacopo Sannazaro itaaliakeelset lamburiromaani „Arkaadia” (1504), kus kasutati taas kõiki Vergiliuse „Ekloogidest” tuttavaid teemasid. Aga Sannazaro Arkaadia polnud täis ainult linnulaulu, ülikauneid lillekesi kuuvalgel, rikkalikult lehtes puudest tulvil metsi ja mägesid, puhta pastoraali kõrval tõi autor sisse ka jõuliselt meelelised maastikud, kosed ja kuristikud, et väljendada juba tumedamaid emotsioone (Schama 1995: 531). Oma loominguga kinnistas Sannazaro moodsa arusaama Arkaadiast kui idüllilise õndsuse kadunud maailmast, mida mäletatakse melanhoolsetes kaebelauludes. Schama järgi said Arkaadia algselt metsikud maastikud ja kombed tundmatuseni muudetud XVI sajandi lõpus, sir Philip Sidney ambitsioonikaimas teoses, mida samuti tuntakse pealkirja all „Arkaadia” (täispealkirjaga „The Countess of Pembroke's Arcadia"). Idealiseeritud karjuseelu põimitakse seal mitte alati kõige loomulikumal moel robustsete võitluste ja poliitiliste reetmislugudega ning pastoraalsed elemendid ühendatakse hellenistlikust mudelist võrsuva meeleoluga. Ent Arkaadiast on saanud üksnes ilustatud maastiku metafoor (Schama 1995: 531). Teisisõnu märkame just siin pöördepunkti, kus juba antiigis oma algsest pinnasest lahti juurdunud ja „rändama” asunud Arkaadia muutub loominguks, teiseneb puhtaks poeesiaks.

Kuid loomingulises Arkaadias kohtuvad harmoonia ja kord alati metsikuse ja tõrksusega. Simon Schama põhiväide on, et igasugune (kunstiks saanud) maastik on mõistuse konstruktsioon - „See koosneb samavõrd mälulademetest kui kivimikihtidest" (Schama 1995: 7) -, nii on ka igasugune ümberkujundatud Arkaadia, olgu siis idülliline või metsik, suures osas urbaanse kujutluse maastik: linn vajas metsikust oma kodanike tervise heaks (Schama 1995: 525), linnade kasvamisega oli tekkinud uus vajadus puhta looduse järele ja hakati idealiseerima maastikke või looma täiuslikuna kujutletud paiku. Teisalt sai eramute maavalduste (aedade-parkide) kujundamise mudeliks õdus (unbeastly) pastoraalide maastik ehk helge Arkaadia juba XV sajandi lõpus, kui Vergiliuse looming hakkas levima trükiversioonis (Schama 1995: 530-531). Vahemärkusena olgu mainitud paradoks, et kuigi kreeklased polnud aednikud ja üldse peeti Kreeka maismaad "aianduseks kõlbmatuks" (Hobhouse 2006: 32-33), ei takistanud see roomlasi ega hilisemate ajastute ja teiste rahvaste pargirajajaid ja aiandusarhitekte laenamast kreeklastelt Arkaadia mõistet, mille all sageli mõeldi vähem kultiveeritud või metsikumaks jäetud pargiosa.

Pärast ideaalmaastike pikaaegset domineerimist tuli Arkaadia-motiivi muutus XVII sajandi algul, kui kunstnikud Giovanni Francesco Barbieri (Guercino) (1591-1666) ning Nicolas Poussin (1594-1665) asetasid oma maalidele kirja „Et in Arcadia ego” [„Ka Arkaadias (olen) ma (olemas)”, millega visualiseeriti surma kohalolu maises Arkaadias: mõlemal kunstnikul kujutab ladinakeelne fraas endast epitaafi, sümboliseerides renessansis populaarset memento mori teemat. Itaaliast pärit Guercino maalil „Et in Arcadia ego” (aastatest 1618-1622) esineb see ladinakeelne fraas kunstis üldse esimest korda ning surma rõhutab selgesti epitaafil ilutsev jõle kolp. See teatab ühemõtteliselt, et isegi Arkaadias on tema, surm, olemas (Schama 1995: 519). ${ }^{1}$ Prant-

1 Üsna ühemõtteliselt just Guercino maalile viitab ka Evelyn Waugh’ romaani „Tagasi Bridesheadi” (1945) esimene raamat „Et in Arcadia Ego”: selle ühes episoodis kirjeldatakse suurele roosivaasile asetatud pealuud tollesama ladinakeelse motoga laubal (Waugh 2005: 45), millega Waugh on samamoodi idüllilise unistuste maastiku ilu, Arkaadiaks ja 
susmaalt pärit, kuid oma põhilise loomeaja (1624-1640) Roomas veetnud Poussini kaks sama ladinakeelse fraasiga pealkirjastatud maali (1627, tuntud ka kui „Arkaadia karjased”, ja 1637-1638) viitavad küll Guercinole, kuid neil kujutatud kiri hauakivil tundub olevat ennekõike hõllanduslik järelehüüe kord nauditud ja siis kaotatud pastoraalsele idüllile (Schama 1995: 519). Samas on ilmselgelt näha, et Poussingi on samal maastikul kokku sidunud kaks Arkaadiat, heleda ja tumeda - hirmu ja koleduse pime Arkaadia on leidnud tee õrna, harmoonilisse idülli (Schama 1995: 561).

Nagu eelnevast näha, kerkis just Itaalia maastikel loodud kunstis esile Arkaadia-motiivi sünge pool, mis viitab geograafilise originaalmaastiku algsetele, näiteks paanilist hirmu toitvatele omadustele - pidagem seda asjaolu silmas eriti Karl Ristikivi maastikulise Arkaadiani jõudmisel!

Ent XVIII sajandi algul muutus arhailine Arkaadia taas nähtavaks kogu Euroopas, kui hakati väärtusena ülistama „algelist metslust” ning maastike kirjeldamisel said sagedasteks terminiteks "toorus/jõhkrus” ja "segadus” (Schama 1995: 538). Schama järgi ongi seetõttu alati olemas kaks Arkaadia tüüpi, mis jätkavad oma rändu ka modernses kultuurimälus. Kord domineerib üks - tokerjas, metsik, hämar, ihade tume salu, hulluse ja surma labürint, ürgse paanilise hirmu ja ettearvamatute elamuste paik -, kord jällegi teine: idülliline, kultiveeritud, sile ja hele, helge bukoolilise rahu ning vabaolu paik (Schama 1995: 517, 522, 570).

Küsigem järgnevalt, millisest kultuuriloolisest või geograafilisest punktist lähtub Ristikivi teoste Arkaadia-motiivi arendus ja kuhu paigutub heledusetumeduse skaalal Ristikivi enese loodud Arkaadia.

\section{Igatsuste Arkaadia}

Ristikivi Arkaadia-teekonna alguses on tema kolmas suur ja tõsiseltvõetav romaan, haritlase kujunemise lugu „Rohtaed” (1942), mis muu kõrval kätkeb piibliallusioonegi. Ei saa teisiti mõista seda, kuidas Arkaadia kerkib lugeja ette paradiislikuna ja sealt on võimalik olla välja aetud, nagu romaanis öeldakse peategelase kasupoja Tiit Neideri kohta, kelle jaoks Arkaadia oli imemaa luules (Ristikivi 2008b: 323). Antiikse, hellenite ja roomlaste Arkaadia kõrval on see väljaajamise võimalus siiski väike, kuid õigeusklikule Ristikivile vältimatult omane kõrvalehüpe. Teiselt poolt raamistab romaani ühtaegu nii kristlik kui ka harituse rõhutamise tähenduses valgustuslik oma aia harimise motiiv, ${ }^{2}$ mis Juulius Kilimiti isikus kulmineerub ühtaegu leppimises ja rahulolus oma argise kooliõpetajatööga ning reaalse koduaia hooldamisega.

„Rohtaia” Arkaadia muutlikkuses on nähtud kolme staadiumi: ihaluse, päralejõudmise ja resignatsiooni läbimist (Ruutsoo 1988: 82). Ennekõike on see siiski resignatsioonitendentsi ning seetõttu tumedate varjudega mentaal-

imedemaaks nimetatud Bridesheadi avastamise etapi varjundanud vastuolude ja tumedusega. Seda kirjandusvõtet on märganud kunstiajaloolane Erwin Panofsky, kes just Poussini töid analüüsides on lahti kirjutanud moto „Et in Arcadia Ego” kaks põrkuvat - heleduse ja tumedusena - tähendust (raamatus „Meaning in the Visual Arts”, 1955).

2 Vahemärkusena võib samasugust oma aia harimise vajadust täheldada kakskümmend viis aastat hiljem ka romaani „Nõiduse õpilane” protagonisti Johannes Faberi puhul (vt Ristikivi 1994: 144), mis on „Rohtaiaga” liiga ilmne paralleel, et olla juhuslik. 
se omailma metafoor. Juulius Kilimiti jaoks algab Arkaadia roomlaste antiigipärandi tundmaõppimisest, vaimseis pürgimusis liigub Friedrich Schilleri „Kreeka jumalate” lugemise kaudu geograafilise ja müütilise KreekaArkaadia kujuteldavasse lähedusse, edasises muutub juba imaginaarseks Kreeka ideaalmaastikuks, mis toidab unistusi ilusa Hellase asuursinisest taevast, loorberitest ja küpressidest (Ristikivi 2008b: 34). Resignatsioonis saab sellest aga igatsuste ruum, sümboolne poolmuinasjutuline unistuste maailm, „lihtsameelse idealismi Arkaadia” (Ristikivi 2008b: 441), kuhu tegelikkuse eest pageda. Seosed geograafilise Arkaadia maastikega jäävad siin pelgalt vaimsete püüdluste, kujutluste ja igatsuste-unistuste tasemele, mis on enesestmõistetav, kuivõrd Ristikivi pääses (pagulase Soome- ja Rootsi-kogemusi arvestamata) päriselt välismaale reisima esmakordselt 1950. aastal (Pariisi) ning Vahemere maadesse jõudmiseks kulus veel kuus aastat.

Selles mõttes mõistab 1950. aastal kirjutatud luuletus "Minagi olin Arkaadia teel...” Arkaadia-motiivi samamoodi kui varasem „Rohtaed”. Niisugune Arkaadia on kaugel vahetutest maastikulistest elamustest, selles nähakse ühtaegu vaimsete ponnistuste sümboolset sihti ja nende luhtumist, lisaks liidab kirjanik sinna omaeluloolise seesmise elupaguluse. Selles Ristikivi ilmselt tuntuimas luuletuses väljendub samuti resignatsioon ning päralejõudmatus Arkaadia teel: „Aga ma tean, et kaotasin käest / tee juba enam kui ammu, / ja et ma üksinda enese väest / leiaksin tee, mille kaotasin käest, / selleks ei ole mul rammu" (Ristikivi 2003: 37). Nõnda ka Juulius Kilimit ei leidnud oma Arkaadiat, aga midagi siiski: „Ta oli leidnud oma igatsuse Arkaadia järele" (Ristikivi 2008b: 180).

\section{Itaalia maastikuline Arkaadia}

Erinevalt romaanitegelasest Juulius Kilimitist leidis Karl Ristikivi siiski üles oma konkreetse ja maastikulise Arkaadia asuursinise taeva ja küpressidega - kuigi mitte Hellases, vaid hoopis Itaalias. Ristikivi esimesele Itaaliareisile maikuus 1956 järgnes 1958. aastal teine. Reisikirjas „Itaalia capriccio” neid kokku võttes kirjutas ta: „Olgu nii! See on siiski minu Itaalia, minu album amatöörfotodega, ja vähemalt ma ise oskan neile värvid juurde mõtelda. Siis saab sellest Arkaadia, kus ka mina olen olnud. Sest mulle on Itaalia siiski eeskätt Arkaadia, tänapäeva Itaalia. Antiikne Rooma on surnud, renessanss on talletatud muuseumidesse. Aga Vahemeri on endiselt sinine, apelsinipuud õitsevad samal ajal kui nad vilja kannavad, müürid hõõguvad päikesepaistes, eeslid ja naised kannavad ühesuguse rahu ja väärikusega oma koormat. Ja siiski õnnelik Itaalia, õnnelik isegi vaesuses ja viletsuses, tantsiv ja laulev tulemägede jalal. Midagi on siit ka õppida - kuidas elada ja elu taluda" (Ristikivi 1993: 73). Siin on Arkaadia juba otseselt seotud visuaalse tähendusega ning tunnistatakse võõrdumist „Rohtaia” antiigiihalusest kantud vaimsest Arkaadiast. Reisikirjas liigitab Ristikivi Rooma linna kolmeks: esiteks „antiikaja Rooma, senaatorite ja keisrite linn”, teiseks „paavstide Rooma” ja kolmandaks „tänapäeva Rooma, piiniate ja küpresside, lillede ja fontäänide linn" (Ristikivi 1993: 46-49). Esimene, antiikne Rooma, on Ristikivi jaoks pigem masendav ega kõneta teda kuidagi, milles võimegi näha distantseerumist Juulius Kilimiti igatsustest. Et Ristikivi 43-aastaselt esmakordselt 
kogetud Itaaliat koos Roomaga ikka nimetas oma Arkaadiaks, on võimalik tänu sellele, mida ta nägi oma liigituse kolmandas linnatüübis. Ja pole kahtlust, et tollal, esimestel Itaalia-reisidel, nägi Ristikivi enda ees Arkaadia heledamat poolt, Vahemere-hõngust, piiniate ning küpresside aroomist vallatud päiksesäralist õndsuspaika.

Paarkümmend aastat hiljem ilmunud ja Ristikivi viimaseks romaaniks jäänud „Rooma päevikut” (1976) võib käsitleda kui ajas settinud reisikirja, milles peituvad kirjaniku enese mitmete Rooma-külastuste kihid. Et raamat sisaldab Ristikivi elamuste somnambuulseid peegeldusi ja teadlikku inspiratsiooni otsimist Rooma linnamaastikest, seda tõestavad mitmed viimaselt, 1971. aastal ette võetud Rooma-reisilt saadetud kirjad ja postkaardid. Kunagine, „Itaalia capriccios” valitsenud Rooma ja Itaalia esmaavastamise värskus ja toonane hele Arkaadia-elamus on Kaspar von Schmerzburgi „Rooma päevikus" tuhmunud. Ka Kaspar on käinud Roomas varemgi (ilmselt 1753), ent tema teine retk Rooma 1765. aastal vahendab hilisristikivilikke tundmusi ja sünget maastikunägemust: „Olen juba ammu märganud, et on midagi iseäralikku Itaalia maastikuga - see on kaugelt vaadates alati palju ilusam kui lähedalt. Nagu oleks kunstnik selle maalinud silmapiirile pingutatud lõuendile, mida tulebki ainult eemalt nautida, sest kui ligidale jõuad, näed ainult pragunenud, tuhmunud värve ja väriseva käega veetud joonte riga-räga, kõik on lagunenud, räsas ja räpane" (Ristikivi 1976: 10). Selles kirjelduses nagu ka mujal romaanis puudub igasugune helgus ja idüllilisus. Otsesõnu „Rooma päevikus" Arkaadiat küll mainitud ei ole, kuid tähele tasub panna, et Kaspar rändab täpselt samadel maastikel, kus Ristikivi kord oli tundnud ära oma isikliku Arkaadia. Kaspari Rooma aga vastandub varasemale, Ristikivi reisikirjas talletatud heledale Arkaadia-elamusele. See on seda tähelepanuväärsem ja rõhuvam, et Kaspar saabub Rooma just maikuus keset kõige õitsvamat kevadet, täpselt nagu Ristikivi ise nii oma esimesel kui ka viimasel Rooma-reisil 1971, ja tema esimese ajaloolise romaani „Põlev lipp” (1961) kangelane lapskuningas Konradin von Hohenstaufen saabub Rooma ilusal ning rahulikul suveajal. Tunnetuslikud paralleelid Ristikivi ja tema igavesti nooreks jääva romaanitegelase vahel on ilmsed. Kuningas Konradin ei aima ette oma peatset hukku, tema ja tema looja esimeste Rooma-retkede maailm on hele ja rõõmus. Kaspar aga, nagu ka viimase Rooma-retke Ristikivi, kogeb tumedat Arkaadiat, mis tõepoolest sarnaneb hulluse ja surma labürindiga. Niisiis võime Ristikivi erinevatel aegadel kogetud Roomas ja Itaalias näha samal maastikul! - kohtumas kahte Arkaadiat, metsikut ja õrna, sünget ja heledat.

Seoses Ristikivi rohkete puhkusereisidega Vahemere maadesse ja eriti Kreekasse, kus ta ajavahemikul 1960-1973 käis tervelt üksteist korda, kerkib kindlasti ka küsimus tema isiklikust suhtest alg-Arkaadiasse. Võimalik vastus võiks peituda samuti „Rooma päevikus”, kus peategelane Kasparit näib saatvat selleks ajaks juba kümmekond aastat Roomas viibinud saksa kunstiajaloolase ja arheoloogi Johann Joachim Winckelmanni (1717-1768) vari. Seda enam tundub Kaspari poolelt sõnalt katkenud päeviku põhjal aimatav saatus nagu ennetavat Winckelmanni kurba ja salapärast lõppu Triestes paar aastat hiljem.

Winckelmann avastas enda jaoks Kreeka ja tegi paljud oma järeldused kreeka antiikkultuuri kohta Itaalias leidunud materjali põhjal, ise kordagi 
Kreekas käimata. Õigupoolest oli see tollase Kreeka-vaimustuse väga iseloomulik tunnus, mille üheks põhjuseks oli vahest kuni 1830. aastani kestev Türgi ülemvõim Kreeka aladel. Tegusamaid romantikuid, nagu näiteks lord Byron, viis see küll otseselt vabadusvõitlusse, kuid see oli palju hiljem. Kreekasse ei jõudnud ei J. W. von Goethe ega Fr. Schiller, kellest eriti viimane oli kreeka panteonist vägagi innustunud ja kelle looming sütitas „Rohtaia” Juulius Kilimiti igatsusi. Nõnda puudus nii Kasparil kui ka Ristikivil igasugune vähegi isiklik suhe alg-Arkaadiaga, mõlemad järgivad XVIII sajandi teise poole tuntud Rooma-reisijate ja klassikute avastusradu - teadaolevalt ei külastanud Ristikivi oma Kreeka-reisidel kordagi Peloponnesose sisemaad, piirdudes Mükeene ja Epidaurosega. Vaid mõned Ristikivi romaanitegelased „Viimses linnas” (1962) põikavad oma põgenemisteel Ateenast kirjelduste järgi otsustades poolsaare mägistesse ja metsikutesse piirkondadesse, ent Arkaadiat Ristikivi nimepidi ei nimeta.

On üsna selge, et Ristikivi vaimulaadile sobis rohkem alates Vergiliusest taasavastatud hele, idülliline Arkaadia, mida ta otsis ka korduvalt oma rännuteedel. Kui näha Arkaadia mõistes midagi abstraktselt inimloomusele omast, hingeseisundit peegeldavat suurt üldistust, siis Ristikivi puhul jäävad selle mõistekäsituse heledamale poolele tema intellektuaalse tegevuse puhul rõhutatud kergemeelsus ja mängurõõm, mille üle aga kavatsustest hoolimata „Rooma päevikus” asub domineerima tumedus: „Küllap Sul on õigus, et see siiski on üsna külm raamat. Kuigi mul alguses oli kavatsus kirjutada hoopis teisiti, tundlikumalt ja eelkõige lüürilisemalt. Aga paraku läks kõik teisiti” (Ristikivi 2002: 424). Justkui olnuks süngus midagi nii paratamatult kaasa tõmbavat, et Ristikivil ei olnud „kaotatud meeleolu” enam võimalik uuesti tabada. Kuna tegemist on Ristikivi kõige unenäolisema ja salapärasema romaaniga, võiksime sellest tunnistusest järeldada ka, et autor kaotas kontrolli oma romaani peategelase elu ja surma üle, oskamata seda teost lõpetada teisiti kui katkestades poolelt sõnalt. Nii Kaspari kui ka tema looja hingeseisund oleksid kui vallatud Arkaadia tumedamast poolest.

\section{Skye kui Ristikivi Arkaadia?}

Naaseme nüüd lõpuks pikemalt luuletuse „Minagi olin Arkaadia teel...” juurde, kuigi sellest kronoloogiliselt „Rohtaia” ja „Itaalia capriccio”/,Rooma päeviku" vahele jäävast ning teatud mõttes võtmeluuletusest ei ole varemgi saanud mööda vaadata. Luuletuse, nagu terve „Hårsfjärdeni” tsükli paguluseaegne retseptsioon seletab suuresti selle erakordsust ja uudsust oma ajas ning on hiljem jäänud märkamata, mistõttu on asjakohased mõned väljavõtted. Ristikivi sõber ja esimene biograaf Arvo Mägi, olles nimetanud Ristikivi luuledebüüti „Hårsfjärden” paatoseta ja „pidulik-pühalikuks” meeleolupoeemiks või ka „prohvetikirjadeks”, märgib selle ilmumisaegset konteksti tundes järgmist: „Uudne oli ilmumise ajal meeleoluline vahelduvus, uudne tuntud meloodiate ja võõrkeelsete ridade kasutamine vürtsina, uudne ka maapao meeleolude põimimine poeemiliseks roosikrantsiks vormiliselt niivõrd „kerguse vaimus”, vastuolus siis ikka veel valitseva „sõduriluuleliku” vihase nördimusega ja lohutu pessimismiga. Viimast ei puudu „Hårsfjärdeni” poeetilise laevamatka meeleoludeski, see on siiski enda esialgsetest murrangutest väljavõi- 
delnu küps melanhoolia, mitte heitlik-mässuline negativism" (Mägi 1972: 6). Vist sama, ehk siis paatose puudumist, peab silmas Ants Oras oma repliigiga: „Pasunad ja fanfaarid on talle võõrad” (Oras 1973: 49). Inimese teekonna motiiviga seoses võtab Oras Ristikivi loomingu olemuse kokku kui tema ajalooaineliste romaanide tegelastüüpide sarnasuse, „kes otsivad ja püüavad, kuid ei pääse pärale, kes võitlevad surmani kaotet asja eest. Kuidagi on ta mõjuvaimad kujud kõik saatuse „outsider'id”. Siiski mitte enam outsiderid omaenese hinge suhtes. Neil viirastub ees see, mida omal ajal ilusa eesti sõnaga nimeteti paleuseks. Sihti nad küll ei saavuta, või siis alles surivoodil, nagu see muusikaline geenius, kelle igatset meisterhelind lõplikult kujunes alles siis, kui keegi seda enam kuulda ei suutnud" (Oras 1973: 49). Siin on olulised märksõnad „outsider” ja „paleus” ning Ristikivi romaanitegelaste julge suhestamine tema luulega, samuti kokkuvõte: Ristikivi kangelane ei jõua kunagi ei Ithakasse ega Arkaadiasse, ta on võõral maal ja tema sadam on alati ainult vahepeatus.

Mida neile Ristikivi luulet seletavatele asjatundlikele käsitlustele lisada? Piirdume vähesega, kui tunnistame, et meid huvitab eelkõige luuletuse „Minagi olin Arkaadia teel...” ingliskeelne moto. Kas avavärsiks olev klassikaline fraas ise on laenatud otse Vergiliuselt või pigem Fr. Schillerilt, mis tundub tõenäolisem, või hoopis Goethelt, kes juba oli selle laenanud Schillerilt oma Itaalia-reisikirja motoks, pole kuigi oluline. Samuti on selge, et Arkaadia-motiivi kaastähenduseks on siinkohal viimse piirini viidud memento mori ja luuletus kannab „Rohtaias” omaks kirjutatud kujundi kaudu nüüd juba otseselt autobiograafilist raskust.

Luuletuse moto tõlgendamisel ja selle seostamisel Ristikivi saatusega on Sirje Kiin jäänud peatuma lävepakul, tundes küll ära selle autori Robert Louis Balfour Stevensoni ${ }^{3}$ (1850-1894) ja mööndes suuremeelselt: „Just selle luuletuse olemasolu ... ei luba teha väiklasi oletusi selle kohta, kas autor mõtles Arkaadia all seda või teist Eesti linna, Tallinna või Tartut, Rhodose saart või mõnd Mälari kaljunukki" (Ruutsoo 1988: 84).

Üritame siin minna kaugemale, et mitte öelda - lõpuni. Küsime, kas ja kuidas suhestuvad omavahel Ristikivi luuletuse Arkaadia-motiiv ja moto. Loeme tervet stroofi, mis Stevensoni luuletuses kordub refräänina ja millest Ristikivi on motoks laenanud kaks esimest värsirida:

Sing me a song of a lad that is gone,

Say, could that lad be I?

Merry of soul he sailed on a day

Over the sea to Skye.

Stevensoni luuletuse saamisloost ja selle ajaloolisest taustast on teada järgmist. Tegemist pole puhtal kujul Stevensoni algupärase luuletusega, vaid selle motiiv on laenatud ja loominguliselt edasi arendatud ajaloosündmustest kõnelevast tuntud vanast šoti rahvalaulust „Skye Boat Song”, mille autoriks või üleskirjutajaks peetakse sir Harold Edwin Boultonit (1859-1935). Esimest korda 1884. aastal avaldatud luuletus kõneleb troonipärija prints Charles

${ }^{3}$ Samas on alati täpne toimetaja ja kriitik Hellar Grabbi sedapuhku usaldanud liialt oma intuitsiooni ja omistanud motoks laenatud värsid hoopis teisele inglise luuletajale, Alfred Edward Housmanile (1859-1936) (Grabbi 1999: 140). 
Edward Stuarti (1720-1788) põgenemisest Skye saarele pärast lüüasaamist Cullodeni lahingus 1746. aastal. Süvenemata siin ajaloolistesse üksikasjadesse, võime aga kokku võtta, et Šotimaa populaarsete legendide sinine udu kujundas prints Charlesist järeltulevate põlvkondade jaoks kangelasliku lüüasaamise romantilise sümboli. Laulu „Skye Boat Song” tunneb iga šotlane ning internet pakub sellest kuulamiseks suure hulga erinevaid töötlusi. Kuigi Ristikivi oli ilmselt tuttav ka lauluversiooniga, järgib tema enese luuletus Stevensoni töötluse rütmi, ent ei puuduta seal käsitletavaid ajaloosündmusi, mistõttu tulemus on universaalne ja üldinimlik, ilmse viitega küll maapaole. Ajaloolises mõttes ongi maapagu ainus, mis jääb sir Harold Boultoni ja R. L. Stevensoni luuletust ühendama Ristikivi luule-minaga.

Kuid ühendavaks lüliks on ka Skye saar, ehkki Ristikivi oma luuletuses seda ei maini ja motost on ta sellekohase vihje välja jätnud. Nimelt on kirjanik 23. augustil 1959 kirjutanud oma päevaraamatusse: „Ja National Geographic Magazine'is oli artikkel mu unistuste saarelt Skye. Aga sinna ma vaevalt kunagi pääsen" (Ristikivi 2008a: 140). Aktiivse reisimise perioodil tõmbas Šotimaa teda esialgu võrdselt Kreekaga, 18. mail 1960 on ta kirjutanud: „Arvan, et mulle nüüd jätkub Kreekast juba enam kui küllalt. Kas siiski mitte minna tuleval aastal Šotimaale?" (Ristikivi 2008a: 181). Ent Vahemere maad ja eriti Kreeka on vahepeal jõudnud Ristikivi lummata ja ta järgneb päikese ja oma kreeklasest sõbra Spyros Arvanitise kutsele veel kuni viimase Kreeka-reisini 1973. aastal. Vahest oli põhjuseks ka see, mida Ristikivi isegi 19. juulil 1945 kirjas Valev Uibopuule oli rõhutanud: ta on linnageograaf ja matkamisest eriti ei hooli (KM EKLA, f 356, m 91 : 13). Kreeka tähendas Ristikivile ju ennekõike liikumist kultuurmaastikul.

Šotimaale Ristikivi ometi jõudis, kuigi alles 1975. aastal, millest annab tunnistust ainult 15. juunil 1975 Bernard Kangrole Invernessist saadetud postkaart sõnumiga: „Kuigi Šotimaalt, siiski palju, palju tervisi teile kõigile seal all lagedal. So long! Kröits" (Ristikivi 2012: 202). Juba kümmekond aastat varem päevikus kajastuvaid kurtmisi ja tervisehädasid meenutades näib selline retk „üles põhja” üsna üllatav, seda enam, et teadaolevalt ei olnud Ristikivil seal tuttavaid ega ole $\mathrm{ka}$ andmeid teda sellele reisile meelitanud kolleegide-sõprade kohta. Inverness on 57000 elanikuga linnake Põhja-Šotimaal Põhjamere ääres, suhteliselt eemal kõigist suurtest keskustest. Invernessist läänes umbes 80 miili ehk paaritunnise autosõidu kaugusel asub unistuste saareks nimetatud Skye, Šotimaa suuremaid ja tuntumaid saari. Meil ei ole praeguseni mingeid teateid sellest, kas Ristikivi oma unistuste saarel ka käis. Aga selline lähedus ei saa kõnelda millestki muust kui teelolekust oma unistuse suunas - miks muidu võttis seni Vahemere maade sooja päikse kutset järginud ja end lootusetult vanaks jäänuna tundnud Ristikivi oma viimase reisi ette just põhjapoolsesse askeetlikku piirkonda, Skye lähistele, kui mitte ühendamaks vana armastust romantilise inglise kirjanduse vastu, unelmat ühe troonipretendendi maapaopaigast ja ihalust metsikule põhjamaale rännanud ja sinna imehästi sobituva Arkaadia järele?

Pole vaja kaugelt otsida prints Charlesi saatusekaaslasi. Tema lähim vaste ajaloos ja Ristikivi loomingus on ju ka „Põleva lipu” kangelane, 1268. aastal Itaalias Tagliacozzo lahingus lüüa saanud ja Napolis hukatud kuningas Konradin von Hohenstaufen, kellest muuseas kavandas draamat ka noor Schiller (Lahnstein 1992: 21). Sellises oma kangelastega saatuseühtsuse 
tunnetamises on midagi väga ristikivilikku. Ka Ristikivi tundis end ju pidevalt kaotajana, ja nagu mäletame tema luulest, jääb ka paremal juhul võit ikkagi ainult viigiks. Nii ühendab alati kaotanu võidukaar üle sajandite kirjanikku ja õilsaid ideid kandnud, kuid lüüasaanud trooninõudlejaid.

\section{Kokkuvõtteks}

Anname endile aru, et üht Karl Ristikivi loomingu motiivi jälitaval teekonnal oleme kaugenenud ja ajuti hälbinudki Arkaadiast, mis otsesõnu nimetatuna esinebki vaid kolmes teoses: romaanis „Rohtaed”, luuletuses „Minagi olin Arkaadia teel...” ning reisikirjas „Itaalia capriccio”. Ent kui näha selles võimalust suureks üldistuseks, antud juhul kogu Ristikivi loomingu üle laotuvat katusmõistet? Umbes nii, nagu Arkaadiat määratleda püüdes jõudis Kreeka ja Rooma klassikute parimaid tundjaid Jaan Unt otsiva ja mõtlemisvõimelise isepäisuse maastikuni (Unt 1999). Muuseas, Arkaadiaga seoses meenuski Undile kõigepealt ei miski muu kui Ristikivi luuletus. Nagunii on tegemist ammu enne Ristikivi oma algsest pinnasest lahti juurdunud ja rändama läinud motiiviga. Kõik meile tuntud kirjanduslik-kultuuriline on quasiArkaadia (Unt 1999). Aga kui näha sellel motiivil erinevaid varjundeid, tumedusest, ohtudest tulvil metsikust tihnikust heledusse, päiksesäras välule kulgevat telge?

Selle vaateviisi järgi püsib Ristikivi oma kirjanduslikus arengus ideaalis varajaste roomlaste eeskujul skaala heledal poolel. „Rohtaias” valmis kirjutatud Arkaadia-motiiv on viljastanud Ristikivi edasist loomingut, ent põrganud hiljem tagasi panhelleenilise ehk üldkreekaliku ürgsuse ees, eelistades rohkem kultiveeritud, viimistletud, turvalist, teadvuse kontrollile alluvat süstee-

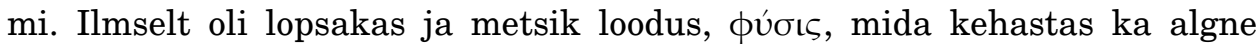
Arkaadia, apolloonilise loojatüübi jaoks, nagu Ristikivi seda kahtlemata oli, liiga kaootiline, ohjeldamatu, organiseerimata. Ehk liiga dionüüsiline? „Rooma päeviku" kirjutamise aegu Ristikivi vallanud süngetele meeleoludele pakkus tasakaalustavat jõudu talle kahtlemata loomuomasem Põhja-Šotimaa saare Skye askeetlik loodus, isegi kui see jäi ainult igatsuseks, ja oma loomingus juba kinnistatud helge Arkaadia viimne nägemine selles.

\section{Käsikirjalised allikad}

Karl Ristikivi kirjad Valev Uibopuule 17. XI 1944-3. V 1975 ja d-ta. KM EKLA, f $356, \mathrm{~m} 91: 13$.

\section{Kirjandus}

F r i e d e 11, Egon 2010. Vanaaja kultuurilugu. Eelkristliku ajastu vaimu elu ja legend. II. Kreeka kultuurilugu. Tallinn: Eesti Keele Sihtasutus.

G r a b b i, Hellar 1999. „Ingel mõõgaga on ees...”: fragmentaarium Ristikivist. H. Grabbi, Tulgu uus taevas. Mõtteid viiekümnest kirjanikust. Tallinn: Virgela, lk 136- 143. 
H o b h o u s e, Penelope 2006. Aianduse ajalugu. Tallinn: Varrak.

K a n g r o, Bernard, R i s tikivi, Karl 2006. Kirjad romaanist. 31 kirja aastaist 1966-1977. Tallinn: Varrak.

L a h n s t e in, Peter 1992. Schilleri elu. Tallinn: Eesti Raamat.

M ä g i, Arvo (Ar-gi) 1972. Trööstiteekond avaruses. - Teataja 25. XI, lk 6.

Or a s, Ants 1973. Inimese teekond. - Tulimuld, nr 1, lk 49-50.

Oras, Ants 1992. Vergiliuse pastoraalid. - Publius Vergilius Maro, Bucolica. Aeneis. Tõlkinud Ants Oras. Tallinn: Sihtasutus Hortus Litterarum, lk 11-14.

P u h ve l, Jaan 1997. Võrdlev mütoloogia. (Eesti mõttelugu 12.) Tartu: Ilmamaa.

R i s t i k vi, Karl 1976. Kaspar von Schmerzburgi Rooma päevik. Lund: Eesti Kirjanike Kooperatiiv.

Ristikivi, Karl 1993. Itaalia capriccio. - Karl Ristikivi, Mälestusi ja reisikirju. - Loomingu Raamatukogu, nr 1-2. Tallinn: Perioodika, lk 37-73.

R i s tikivi, Karl 1994. Nõiduse õpilane. Tallinn: Eesti Raamat.

R i s tiki vi, Karl 1995. Karl Ristikivi kiri Otto A. Webermannile. - Eesti Kirjanduse Seltsi aastaraamat XXV (1994). Tartu: Eesti Kirjanduse Selts, lk 81-84.

Ristikivi, Karl 2002. Valitud kirjad 1938-1977. Tartu: Eesti Kirjandusmuuseum.

R i s t ikivi, Karl 2003. Inimese teekond. Luuletusi. Tallinn: Varrak.

R i s t i k vi, Karl 2008a. Päevaraamat 1957-1968. Tallinn: Varrak.

R is tiki vi, Karl 2008b. Rohtaed. Neljas trükk. Tallinn: Pegasus.

Ristikivi 2012 = Karl Ristikivi teekonnad. Kaheksakümmend kuus postkaarti reisidelt 1946-1976. Kommenteerinud ja koostanud Janika Kronberg. Tartu-Tallinn: Go Group.

Ru uts o o, Sirje 1988. Vergilius, Ristikivi ja P.-E. Rummo Arkaadia teel. Ühe motiivi tunnetusliku tõlgenduse võimalusi. - Karl Ristikivi 75. Karl Ristikivi 75. sünnipäevale pühendatud konverentsi materjalid II. 4. detsember 1987. Tallinn: Eesti NSV Kirjanike Liit, lk 75-87.

S c h a m a, Simon 1995. Landscape and Memory. New York: Alfred A. Knopf. Un t, Jaan 1999. Et Ego in Arcadia. - Eesti Päevaleht: Arkaadia 13. XI, lk 8.

W a u g h, Evelyn 2005. Tagasi Bridesheadi. Kapten Charles Ryderi taevased ja maised mälestused. Tallinn: Varrak.

\section{Karl Ristikivi's Wandering Arcadia}

Keywords: Karl Ristikivi's oeuvre, motif of Arcadia in European cultural history, light and dark Arcadia, creative landscapes, Isle of Skye as a dreamland

Since antiquity the motif of Arcadia has been productive in European cultural history, while undergoing several metamorphoses. The article follows the evolution of the motif in the oeuvre of Karl Ristikivi (1912-1977), relying on the landscapes experienced by the widely travelled author and the works of art critic and theorist Simon Schama, who emphasizes the Light and Dark in Arcadia.

Ristikivi overtly mentions the motif of Arcadia in three works, notably, the novel Rohtaed („The Herb Garden”, 1942), the poem Minagi olin Arkaadia teel... („I too was heading for Arcadia...”, 1950) and the travelogue Itaalia capriccio („Italian Cappriccio”, 1958). In Ristikivi's ideals, Arcadia is a bright dreamland, obviously situated in Italy. The original Hellenic Arcadia did not appeal to Risti- 
kivi's Apollonian nature. Thus he followed the European tradition where Arcadia had already been disassociated from the Greek region of the same name. The poem being inspired by R. L. Stevenson's treatment of the old Scottish ballad „Skye Boat Song", Ristikivi's version suggests that one of his Arcadias might be found on the ascetic Isle of Skye, which most likely was the main destination of the last journey of the aging writer.

The article points out that Arcadia could be interpreted as a generalization including polar opposites, a light-dark axis enabling analysis of Ristikivi's oeuvre as a whole.

Janika Kronberg (b. 1963), MA, literary historian, Director of Estonian Literary Museum, janika@kirmus.ee

Brita Melts (b. 1984), MA, doctoral student at the Institute of Cultural Research and Fine Arts, University of Tartu, ephemera@ut.ee 